\title{
Faktor yang Memengaruhi Perilaku Konsumsi Alkohol Anak Jalanan di Kota Kediri
}

\author{
Esta Ruri Solecha ${ }^{1}$, Diah Indriani ${ }^{2}$ \\ 1,2 Jurusan Biostatistika Kependudukan \\ Fakultas Kesehatan Masyarakat, Universitas Airlangga \\ Alamat korespondensi: J1. Srikana No. 148 Surabaya \\ E-mail korespondensi: estarurisolecha@gmail.com
}

\begin{abstract}
The behavior of alcohol consumption among street children is a serious health problem, because the behavior can have a negative impact. This behavior occurs due to imperfect social interaction in the community and life within the family of street children. This study aims to determine the factors that influence the behavior of alcohol consumption in street children in Kediri. This research method using quantitative approach method. The population in this study is all street children in Kediri with the criteria of adolescents ie age 10-19 years. The sample used in this study were 30 respondents, using accidental sampling method. The variables used are alcohol consumption behavior, attitude, knowledge, affordability, and peers. Data were collected using questionnaire and data analysis using Chi-square test. The results showed that of 30 street children respondents $76.7 \%$ consumed alcohol. The result of Chi-square test shows that the level factor of knowledge, attitude, affordability and environment of peers who have many opportunities to perform alcohol consumption behavior is the affordability factor with OR $=15.8$. This means that the easier a person to get an alcoholic drink the greater the chance to behave alcohol consumption.
\end{abstract}

Keywords: adolescent, street children, alcohol consumption behavior

\begin{abstract}
ABSTRAK
Perilaku konsumsi alkohol di kalangan anak jalanan adalah masalah kesehatan yang cukup serius, karena perilaku tersebut dapat berdampak negatif. Perilaku ini terjadi akibat tidak sempurnanya interaksi sosial pada masyarakat dan kehidupan di dalam keluarga anak jalanan. Tujuan penelitian ini adalah untuk mengetahui faktor yang berpengaruh terhadap perilaku konsumsi alkohol pada anak jalanan di Kota Kediri. Penelitian ini menggunakan metode kuantitatif. Populasi pada penelitian ini adalah seluruh anak jalanan di Kota Kediri dengan kriteria remaja yaitu usia 10-19 tahun. Sampel yang digunakan pada penelitian ini sebanyak 30 responden, dengan menggunakan metode accidental sampling. Variabel yang digunakan adalah perilaku konsumsi alkohol, sikap, pengetahuan, keterjangkauan, dan teman sebaya. Pengumpulan data menggunakan kuesioner dan analisis data menggunakan uji Chi-square. Hasil penelitian menunjukkan bahwa dari 30 orang responden anak jalanan sebesar 76,7\% mengonsumsi alkohol. Hasil dari analisis uji Chi-square menunjukkan bahwa faktor tingkat pengetahuan, sikap, keterjangkauan dan lingkungan teman sebaya yang memiliki peluang banyak untuk melakukan perilaku konsumsi alkohol adalah faktor keterjangkauan dengan nilai $\mathrm{OR}=15,8$. Hal ini berarti semakin mudah seseorang untuk memperoleh minuman beralkohol maka semakin besar peluang untuk berperilaku konsumsi alkohol.
\end{abstract}

Kata kunci: remaja, anak jalanan, perilaku konsumsi alkohol

\section{PENDAHULUAN}

Masa remaja adalah masa transisi antara kanak-kanak menuju kedewasaan. Perubahan siklus ini terjadi secara signifikan yaitu interaksi dengan lingkungan sosial yang lebih luas dan memungkinkan remaja dengan pola berpikir abstrak. Pada masa remaja inilah terjadi perkembangan sikap, perilaku dan sifat. Masa remaja membuat seseorang memiliki rasa keingintahuan yang tinggi, ingin mencoba dan ingin merasakan hal baru. Remaja sering mengalami kegelisahan, kebingungan bahkan keguncangan dalam menemukan jati diri mereka (Kusuma, 2015). Kondisi seperti ini menjadikan lingkungan yang ada di sekitar remaja akan sangat menentukan perilaku yang akan terbentuk pada remaja.

WHO (World Health Organization) mengatakan bahwa yang dimaksud remaja adalah dimana seseorang memiliki rentang 
usia 10-19 tahun. Namun menurut Departemen Kesehatan RI No. 25 tahun. 2014, jangka usia remaja selisih 1 tahun dari angka umur maksimal yaitu pada usia 10-18 tahun. Sedangkan menurut BKKBN, jangka usia berada pada kisaran yang lebih besar pada remaja yang belum menikah di usia 10-24 tahun. Kelompok usia remaja di Indonesia yang berada pada angka 10-19 tahun menurut sensus penduduk yang dilaksanakan pada tahun 2010 sebanyak 43,5 juta jiwa dan total jumlah penduduk sekitar $18 \%$ adalah remaja. Diperkirakan jumlah penduduk di dunia berjumlah 1,2 miliar adalah kelompok usia remaja atau sebesar $18 \%$ dari total jumlah penduduk yang ada di dunia (WHO, 2014).

Anak jalanan yang berada di Indonesia merupakan salah satu kategori penduduk di usia remaja. Kebanyakan dari anak jalanan ini adalah remaja yang sudah putus sekolah dan mengamen di pinggir jalan untuk memenuhi kebutuhan mereka. Namun kebutuhan yang dimaksud disini bukan hanya untuk memenuhi kebutuhan primer semata. Menurut anak jalanan kehidupan sosial mereka juga merupakan kebutuhan yang harus mereka penuhi demi mendapatkan pengakuan dari lingkungan. Pendapatan hasil dari mengamen atau menjual koran dan sebagainya, biasa mereka gunakan untuk perilaku menyimpang dan salah satu perilaku menyimpang yang sering dilakukan oleh anak jalanan adalah mengonsumsi alkohol.

Perilaku mengonsumsi minuman beralkohol dewasa ini mulai menjadi masalah yang berkembang di dunia remaja dan terjadi peningkatan konsumennya dari tahun ke tahun. Menurut data WHO pada tahun 2009 yaitu telah tercatat 775 ribu meninggal akibat mengonsumsi minuman beralkohol. Sedangkan berdasarkan data Riskesdas (2010), total penduduk Indonesia yang mengonsumsi alkohol sebesar $4,6 \%$ dan jumlah penduduk paling banyak mengonsumsi alkohol adalah usia produktif, yaitu pada usia 15-34 tahun sebesar 6,7\%.

Terdapat 3 kategori dampak negatif dari konsumsi alkohol secara periodik yaitu dampak psychology, dampak fisik, dampak sosial dan dampak neurology. (Darmawan, 2010). Sedangkan menurut (Freud, 2005) masa remaja adalah masa dimana seseorang mulai mengalami perubahan yaitu adanya perubahan cita-cita merupakan proses pembentukan orientasi masa depan, adanya perubahan psikoseksual. Yusuf (2007) menyatakan bahwa masa remaja memiliki tiga fase yaitu: fase remaja awal pada saat remaja berusia 13-15 tahun, fase remaja madya pada saat remaja berusia 15-18 tahun, fase remaja akhir pada saat remaja berusia 19-22 tahun.

Konsumsi alkohol di kalangan anak jalanan berusia remaja adalah masalah kesehatan yang cukup serius karena minum alkohol berdampak negatif bagi pihak internal (keluarga dan sikap dirinya) maupun bagi pihak eksternal (teman sebaya dan lingkungannya). Kebiasaan akan meminum minuman beralkohol ini merupakan gangguan yang kompleks pada perspektif biopsychosocial. Istilah ini dapat juga diartikan sebagai gangguan pada sistem kekebalan fisik tubuh, psikis manusia serta akan berimbas pada kehidupan sosialnya (Karsono, 2006). Di Indonesia juga terdapat penderita yang dirawat karena ketergantungan obat-obatan terlarang yaitu sebesar 30\% dari jumlah peminum alkohol. Penelitian tersebut membuktikan bahwa perilaku konsumsi alkohol dapat berdampak negatif berupa penggunaan obat-obatan terlarang.

Selain itu, terdapat penelitian terdahulu yang serupa yaitu tentang pelajar yang mengonsumsi alkohol. Penelitian tersebut dilakukan di sebuah kota di Indonesia oleh Prof Soejono yang merupakan pakar ilmu kedokteran jiwa. Beliau menyatakan bahwa sebesar 50\% pelajar yang telah diteliti hampir seluruhnya pernah mengonsumsi alkohol. Sedangkan menurut Hawari (2006), penyebab terjadinya seseorang mengonsumsi minuman beralkohol adalah terdapat pada diri seseorang tersebut, yang dimaksud adalah rasa ingin mencoba dan merasakan minuman tersebut. Kejadian seperti ini dapat menimbulkan perasaan euforia, logore, hiperaktif, dan dapat merusak organ tubuh. Mengonsumsi alkohol dapat menyebabkan gangguan pada tubuh berupa kekurangan darah dan kurang bergairah.

Ketergantungan terhadap minuman keras ini sering sekali dimulai oleh seseorang dengan mencoba karena seseorang tersebut ingin dapat memiliki hubungan baik dengan temannya, atau hanya untuk acara jamuan makan, acara pesta atau syukuran, serta camilan wajib ketika sekedar berkumpul untuk menghabiskan waktu senggang. Hal-hal negatif yang terjadi di 
lingkungan sekitar mereka inilah yang kemudian dilakukan oleh anak jalanan hingga berujung pada ketergantungan dan ketagihan.

Ketergantungan dan kebiasaan ini beralih pada hal yang biasa dan bukan lagi menjadi hal yang tabu sehingga diperlukan sebuah proses yang cukup singkat untuk mengubah perilaku menjadi kebiasaan mengonsumsi minuman keras. Hal ini banyak terjadi terutama pada fase perkembangan dinamis dalam kehidupan yang berjalan di usia mereka, sehingga masa remaja merupakan peri adalah masa transisi dari anak-anak menuju dewasa (Narendra, 2002).

Waluya (2007) menyatakan penyimpangan dengan mengonsumsi alkohol terjadi akibat tidak sempurnanya sosialisasi yang terjadi baik pada pergaulan di masyarakat maupun kehidupan di dalam keluarga yang mereka anggap tidak sesuai dengan apa yang diharapkan. Sehingga remaja akan mencari pelarian di luar rumah dan lebih memilih untuk bergaul dengan teman sebayanya. Menurut mereka, bersama teman akan dapat memberikan perlindungan dan pengakuan mengenai keberadaan dirinya.

Pada kasus penyimpangan perilaku konsumsi alkohol di beberapa kelompok anak jalanan, biasanya anggota baru dalam kelompok tersebut diharuskan untuk mencoba sesuatu yang menyimpang terlebih dahulu (meminum alkohol, penyalahgunaan narkoba, seks bebas, tindak kekerasan, dan sebagainya.). Hal ini dilakukan untuk membuktikan seseorang tersebut layak tidak masuk ke dalam kelompok anak jalanan yang diakui/terkenal di lingkungannya. Kegiatan tersebut dilakukan untuk mendapatkan pengakuan tentang kedewasaan seseorang serta pengakuan dari kelompok hingga menjadi anggota kelompok tersebut.

Risiko dari perilaku mengonsumsi minuman beralkohol akan mengakibatkan gangguan pada fisik dan psikologis peminumnya. Penelitian yang dilakukan oleh Gerakan Nasional Anti Miras pada tahun 2013 mengemukakan bahwa sebesar 4\% kejahatan yang terjadi di Kota Jakarta disebabkan oleh pelaku pengonsumsi miras. Sementara itu, Berdasarkan data yang dikutip oleh (Mulyadi, 2014), tentang data satuan Resor Narkoba Polres Blitar. Polres tersebut menegaskan bahwa telah menangani sebanyak 226 kasus kejahatan minuman beralkohol pada tahun 2012.
Terdapat peningkatan jumlah kasus kejahatan yang signifikan dari tahun 2011 sebanyak 178 kasus. Di sisi lain, Kasatreskrim Polda Metro Jaya menyatakan bahwa minuman beralkohol yang dijual di pasaran sangat tidak sesuai dengan standar kesehatan yang berlaku dan rentan bagi fisik dan bagi kesehatan peminumnya. Dampak negatif yang akan dirasakan setelah meminumnya tetap tidak dihiraukan oleh mereka.

Adanya perilaku negatif yang ditimbulkan dari konsumsi minuman keras ini dirasa memerlukan perhatian yang serius pada jumlah remaja yang cukup besar dan adanya penggolongan remaja terutama pada anak jalanan yang sebagian besar sudah putus sekolah dan dari keluarga bermasalah ini. Anak jalanan yang masih usia sekolah, memasuki usia kerja dan umur reproduksi akan berpotensi menimbulkan permasalahan berisiko tinggi. Perilaku berisiko yang dapat dilakukan pada usia remaja ini berhubungan dengan perkembangan kepribadian dan adaptasi sosial dari kelompok anak jalanan dan pada lingkungan remaja.

Menurut Nurwijaya (2009) tentang survei penggunaan alkohol dan obat pada tahun 2005 di Amerika, sebesar 51,8\% penduduk amerika usia 12 tahun ke atas sudah pernah mengonsumsi alkohol. Penduduk laki-laki menjadi pecandu alkohol 4 kali lebih sering dibandingkan perempuannya. Penduduk dari berbagai kelompok umur bisa terkena.

Berdasarkan latar belakang diatas, Tujuan dari penelitian ini adalah untuk menganalisis faktor yang mempengaruhi perilaku konsumsi alkohol pada anak jalanan di Kota Kediri.

\section{METODE PENELITIAN}

Penelitian ini menggunakan metode pendekatan kuantitatif. Penelitian ini adalah penelitian obervasional. Berdasarkan waktu pengambilan datanya, penelitian ini merupakan penelitian cross sectional. Populasi pada penelitian ini anak jalanan yang berusia remaja yaitu 10-19 tahun yang sering mengamen di kota Kediri, Jawa Timur. Sampel pada penelitian ini berjumlah 30 anak jalanan/terlantar yang berusia remaja yaitu 10-19 tahun di lokasi penelitian yang dilakukan di pinggir jalan dekat dengan traffic light area Kota Kediri, Jawa Timur. 
Teknik sampling dalam penelitian ini menggunakan accidental, sehingga dalam teknik sampling peneliti mengambil responden pada saat itu juga dari hari Senin sampai Minggu di perempatan jalanan Kota Kediri yang sering digunakan anak jalanan untuk mencari uang dan mengamen. Jumlah sampel yang didapatkan selama satu minggu sebanyak 30 orang responden anak jalanan. Teknik dalam pengumpulan data pada penelitian ini yaitu dengan pengambilan data primer yang diperoleh langsung dari tempat penelitian, alat yang digunakan untuk pengumpulan data yaitu menggunakan kuesioner terbuka dan tertutup.

\section{HASIL PENELITIAN}

Tabel 1 menunjukkan sebanyak 23 responden mengonsumsi alkohol dengan nilai presentase sebesar $76,6 \%$. Sedangkan sebanyak 7 responden diantaranya mengaku tidak mengonsumsi alkohol dengan nilai presentase sebesar $23,3 \%$. Mereka mengatakan belum pernah mencoba minuman beralkohol.

Tabel 2 menunjukkan bahwa usia dominan responden adalah 17 tahun. Sejumlah 14 orang responden berusia 17 tahun dengan nilai presentase sebesar $46,6 \%$. Sedangkan responden yang memiliki usia termuda adalah 16 tahun sebesar $20 \%$. Sebagian besar responden anak jalanan yang berusia (16-19 tahun) adalah

Tabel 1. Distribusi Frekuensi Perilaku Konsumsi Alkohol Anak Jalanan di Kota Kediri

\begin{tabular}{lcc}
\hline $\begin{array}{c}\text { Konsumsi } \\
\text { Alkohol }\end{array}$ & Jumlah & Persentase (\%) \\
\hline Ya & 23 orang & 76,6 \\
Tidak & 7 orang & 23,3 \\
\hline Total & 30 orang & 100 \\
\hline
\end{tabular}

Tabel 2. Distribusi Frekuensi Usia Responden Anak Jalanan di Kota Kediri

\begin{tabular}{lrc}
\hline Usia (Tahun) & Jumlah & Persentase (\%) \\
\hline 16 tahun & 6 orang & 20 \\
17 tahun & 14 orang & 46,7 \\
18 tahun & 6 orang & 20 \\
19 tahun & 4 orang & 13,3 \\
\hline Total & 30 orang & 100 \\
\hline
\end{tabular}

pengonsumsi alkohol aktif. Konsumsi alkohol aktif adalah responden yang menyatakan pada saat ini masih mengonsumsi alkohol. Hal ini merupakan satu bentuk perilaku menyimpang berbahaya bagi kesehatan dan kelangsungan hidup mereka.

Seluruh responden anak jalanan pernah bersekolah. Mayoritas tingkat pendidikan terakhir responden adalah SMP yaitu sebanyak 21 orang dengan presentase $70 \%$, sedangkan pendidikan terakhir SD sebanyak 1 orang dengan presentase sebesar 3,3\% (Tabel 3).

Enam belas orang atau sebesar 53,3\% memiliki sikap yang tidak baik terhadap perilaku konsumsi alkohol. Responden dapat dikata tidak baik jika tetap mengonsumsi alkohol walaupun sudah dinasehati keluarga maupun teman sebayanya. Mereka yang konsumsi alkohol akan mempengaruhi temannya untuk mengonsumsi juga. Sementara itu, responden yang memiliki sikap baik terhadap perilaku konsumsi alkohol sebanyak 14 orang atau sebesar $46,7 \%$ (Tabel 4).

Tabel 5 menunjukkan bahwa sebesar 63,3\% responden memiliki pengetahuan kurang tentang minuman beralkohol. Sedangkan sebesar 23,3\% responden memiliki pengetahuan sedang dan sisanya berpengetahuan baik. Responden dapat dikatakan tingkat pengetahuan kurang, sedang atau baik berdasarkan skor kuesioner. Kuesioner

Tabel 3. Distribusi Frekuensi Pendidikan Terakhir Responden Anak Jalanan di Kota Kediri

\begin{tabular}{lcc}
\hline $\begin{array}{c}\text { Tingkat } \\
\text { Pendidikan }\end{array}$ & $\begin{array}{c}\text { Jumlah } \\
\text { Responden }\end{array}$ & Persentase (\%) \\
\hline SD & 1 orang & 3,3 \\
SMP & 21 orang & 70 \\
SMA & 8 orang & 26,6 \\
\hline Total & 30 orang & 100 \\
\hline
\end{tabular}

Tabel 4. Distribusi Frekuensi Sikap Responden terhadap Konsumsi Alkohol

\begin{tabular}{lcc}
\hline \multicolumn{1}{c}{ Sikap } & $\begin{array}{c}\text { Jumlah } \\
\text { Responden }\end{array}$ & Persentase (\%) \\
\hline Baik & 14 orang & 46,7 \\
Tidak Baik & 16 orang & 53,3 \\
\hline Total & 30 orang & 100 \\
\hline
\end{tabular}


Tabel 5. Distribusi Frekuensi Tingkat Pengetahuan Responden terhadap Minuman Beralkohol

\begin{tabular}{lcc}
\hline $\begin{array}{c}\text { Tingkat } \\
\text { Pengetahuan }\end{array}$ & $\begin{array}{c}\text { Jumlah } \\
\text { Responden }\end{array}$ & Persentase (\%) \\
\hline Baik & 4 orang & 13,3 \\
Sedang & 7 orang & 23,3 \\
Kurang & 19 orang & 63,3 \\
\hline Total & 30 orang & 100 \\
\hline
\end{tabular}

tersebut mengenai pengertian, bahaya dan jenis minuman beralkohol.

Tabel 6 dapat diketahui bahwa sebesar $63,33 \%$ menyatakan kemudahan dalam menjangkau minuman beralkohol dan sebesar $46,67 \%$ menyatakan tidak terjangkau terhadap minuman beralkohol. Minuman beralkohol dapat dikatakan terjangkau jika responden mudah mendapatkannya.

Tabel 7 menyatakan bahwa responden yang mendapatkan dorongan dari lingkungan teman sebaya sebesar $63,3 \%$. Sedangkan sebesar $36,7 \%$ mengatakan tidak mendapat mendorong untuk mengonsumsi alkohol.

Tabel 8 dapat diketahui bahwa mayoritas responden yang mengonsumsi alkohol memiliki pengetahuan kurang tentang minuman beralkohol. Hasil analisis uji statistik dengan Chi-square Test didapatkan nilai $\mathrm{OR}=6,9$ artinya tingkat

Tabel 6. Distribusi pada Frekuensi Kerjangkauan Responden terhadap Minuman Beralkohol

\begin{tabular}{lcc}
\hline Keterjangkauan & $\begin{array}{c}\text { Jumlah } \\
\text { Responden }\end{array}$ & Persentase (\%) \\
\hline Terjangkau & 19 orang & 63,3 \\
Tidak Terjangkau & 11 orang & 36,7 \\
\hline Total & 30 orang & 100 \\
\hline
\end{tabular}

Tabel 7. Distribusi Frekuensi Lingkungan Teman Sebaya terhadap Konsumsi Alkohol

\begin{tabular}{|c|c|c|}
\hline $\begin{array}{l}\text { Lingkungan } \\
\text { Teman Sebaya }\end{array}$ & $\begin{array}{c}\text { Jumlah } \\
\text { Responden }\end{array}$ & Persentase (\%) \\
\hline Mendorong & 19 orang & 63,3 \\
\hline Tidak Mendorong & 11 orang & 36,7 \\
\hline Total & 30 orang & 100 \\
\hline
\end{tabular}

Tabel 8. Hubungan Tingkat Pengetahuan terhadap Perilaku Konsumsi Alkohol

\begin{tabular}{lcccc}
\hline Konsumsi & \multicolumn{3}{c}{ Tingkat Pengetahuan } & \multirow{2}{*}{ OR } \\
\cline { 2 - 4 } \multicolumn{1}{c}{ Alkohol } & Baik & Sedang & Kurang & \\
\hline Ya & 1 & 6 & 16 & \multirow{2}{*}{6,9} \\
Tidak & 3 & 1 & 3 & \\
\hline Total & 4 & 7 & 18 & \\
\hline
\end{tabular}

Tabel 9. Hubungan Sikap terhadap Perilaku Konsumsi Alkohol

\begin{tabular}{lccc}
\hline Konsumsi & \multicolumn{2}{c}{ Sikap } & \multirow{2}{*}{ OR } \\
\cline { 2 - 3 } \multicolumn{1}{c}{ Alkohol } & Baik & Sedang & \\
\hline a & 8 & 15 & \multirow{2}{*}{5,6} \\
Tidak & 6 & 1 & \\
\hline Total & 14 & 16 & \\
\hline
\end{tabular}

Tabel 10. Hubungan Keterjangkauan terhadap Perilaku Konsumsi Alkohol

\begin{tabular}{lccc}
\hline \multirow{2}{*}{$\begin{array}{c}\text { Konsumsi } \\
\text { Alkohol }\end{array}$} & \multicolumn{2}{c}{ Keterjangkauan } & \multirow{2}{*}{ OR } \\
\cline { 2 - 3 } & Terjangkau & $\begin{array}{c}\text { Tidak } \\
\text { Terjangkau }\end{array}$ & \\
\hline Ya & 19 & 4 & 15,8 \\
Tidak & 0 & 7 & \\
\hline Total & 19 & 11 & \\
\hline
\end{tabular}

pengetahuan memiliki risiko melakukan perilaku konsumsi alkohol sebesar 6,9 kali.

Tabel 9 menunjukkan bahwa sikap responden dalam kategori tidak baik terhadap perilaku konsumsi alkohol sebanyak 15 orang adalah responden yang mengonsumsi alkohol. Hasil analisis uji statistik dengan Chi-square Test didapatkan nilai $\mathrm{OR}=5,6$ yang artinya faktor sikap memiliki risiko melakukan perilaku konsumsi alkohol sebesar 5,6 kali.

Tabel 10 menunjukkan bahwa sebesar 19 orang responden yang mengonsumsi alkohol menyatakan terjangkaunya minuman beralkohol. Hasil analisis uji statistik dengan Chi-square Test didapatkan nilai $\mathrm{OR}=15,8$ yang artinya anak jalanan memiliki risiko 15,8 untuk menjadi pengonsumsi alkohol dilihat berdasarkan faktor keterjangkauan.

Tabel 11 menunjukkan bahwa mayoritas responden yang mengonsumsi alkohol mendapatkan dorongan dari lingkungan teman sebaya sebanyak 19 orang responden. Sedangkan yang tidak mendapat dorongan sebanyak 9 orang, 
Tabel 11. Hubungan Lingkungan Teman Sebaya terhadap Perilaku Konsumsi Alkohol

\begin{tabular}{lccc}
\hline & \multicolumn{2}{c}{ Lingkungan Teman } \\
Konsumsi & \multicolumn{2}{c}{ Sebaya } & \multirow{2}{*}{ OR } \\
\cline { 2 - 3 } Alkohol & Mendorong & $\begin{array}{c}\text { Tidak } \\
\text { Mendorong }\end{array}$ & \\
\hline Ya & 19 & 4 & 12,8 \\
Tidak & 2 & 5 & \\
\hline Total & 21 & 9 & \\
\hline
\end{tabular}

7 orang diantaranya tidak mengonsumsi alkohol. Hasil analisis uji statistik dengan Chi-square Test didapatkan nilai $\mathrm{OR}=12,8$ artinya faktor sikap memiliki risiko 12,8 kali melakukan perilaku konsumsi alkohol. Hal ini berarti dorongan lingkungan teman sebaya memengaruhi perilaku konsumsi alkohol.

\section{PEMBAHASAN}

\section{Tingkat pengetahuan}

Hasil penelitian menyatakan terdapat hubungan antara tingkat pengetahuan dengan perilaku konsumsi alkohol dengan didapatkan hasil OR $=6,894$, yang artinya anak jalanan berpeluang 6,894 kali untuk melakukan perilaku konsumsi alkohol dilihat dari tingkat pengetahuan.

Hasil analisis pengetahuan ini seusai dengan hasil penelitian Adiputra, dkk (2014) dari 38 responden menyatakan bahwa responden yang memiliki pengetahuan kurang tentang minuman beralkohol meningkatkan risiko terhadap perilaku konsumsi alkohol 4,66 kali lebih besar dari pada yang memiliki pengetahuan baik.

Berdasarkan Tabel 3 tentang pendidikan terakhir yang ditempuh oleh responden, 1 dari 30 responden hanya berpendidikan tamat SD, 29 diantaranya ada yang tamat SMP melanjutkan ke SMA dan ada juga yang memutuskan untuk berhenti sekolah, dikarenakan faktor ekonomi keluarga yang tidak mampu atau mereka lebih memilih kerja dari pada sekolahnya. Seseorang yang memiliki pendidikan tinggi akan lebih mudah menerima masukan, sehingga semakin banyak pengetahuan yang dimilikinya dan sebaliknya seseorang yang memiliki pendidikan rendah akan lebih sulit menerima masukan atau informasi yang baru diperkenalkan. Maka dari itu pendidikan sangat perlu untuk membentuk karakter atau perilaku seseorang.

Teori mengungkapkan bahwa pengetahuan adalah salah satu hal yang dibutuhkan untuk mengubah perilaku dan pola pikir seseorang atau kelompok. Sesuai dengan hasil penelitian, menurut Notoatmodjo (2007) pengetahuan adalah suatu hal yang memiliki nilai terpenting dalam pembentukan perilaku seseorang. Seseorang yang memiliki pengetahuan kurang tentang bahaya konsumsi alkohol cenderung lebih gampang terpengaruh oleh lingkungan sekitarnya untuk konsumsi, sedangkan mereka tidak sadar akan bahaya yang dapat ditimbulkan jika mengonsumsi alkohol terus menerus.

\section{Sikap}

Hasil ini penelitian menunjukkan bahwa terdapat hubungan antara perilaku konsumsi alkohol dengan sikap didapatkan hasil $\mathrm{OR}=5,6$, yang artinya anak jalanan berpeluang 5,6 kali untuk melakukan perilaku konsumsi alkohol dilihat berdasarkan dari sikap.

Penelitian ini sesuai dengan hasil penelitian yang dilakukan oleh Artha (2016) dari 250 responden didapatkan nilai $\mathrm{OR}=14,88$. Hasil penelitian ini menunjukkan bahwa remaja memiliki peluang 14,88 kali untuk melakukan perilaku konsumsi alkohol dilihat berdasarkan dari sikap.

Pendapat Notoatmojo (2007) selaras dengan hasil penelitian ini, yakni perubahan sikap atau perilaku tidak dapat dilihat secara langsung dengan mata namun dapat dirasakan atau ditafsirkan. Seseorang yang memiliki perilaku atau sikap tertutup akan lebih mudah terpengaruh ke hal-hal yang bersifat negative dibandingkan yang bersikap terbuka. Semakin tegas sikap seseorang untuk menolak hal yang bersikap negative (konsumsi alkohol) maka akan berdampak baik.

\section{Keterjangkauan}

Hasil penelitian menyatakan terdapat hubungan antara keterjangkauan dengan perilaku konsumsi alkohol dengan didapatkan hasil $\mathrm{OR}=15,8$ yang artinya anak jalanan berpeluang 15,8 kali melakukan perilaku konsumsi alkohol dilihat dari keterjangkauan 
minuman beralkohol. Maka semakin mudah remaja mendapatkan minuman beralkohol yang mereka inginkan semakin besar pula peluang remaja untuk menjadi pengonsumsi minuman beralkohol. Apabila minuman beralkohol yang dijual di pasaran mudah didapatkan oleh remaja seusia responden, maka akan memicu keinginan responden untuk mencoba konsumsi minuman tersebut. Hasil penelitian yang didapat sejalan dengan hasil penelitian yang dilakukan oleh Kalara (2014) menunjukkan bahwa hal yang dapat memicu responden mengonsumsi alkohol adalah kemudahan responden untuk mendapatkan minuman beralkohol kapan pun mereka inginkan. Menurutnya hal ini dikarenakan semakin banyaknya penjual minuman beralkohol secara bebas misalnya saja pada mini market, cafe, warung remang-remang, hotel, bandara, club sampai warung kecil juga menyediakan minuman tersebut.

\section{Lingkungan teman sebaya}

Hasil penelitian, Tabel 11 tentang hubungan lingkungan teman sebaya didapatkan hasil $\mathrm{OR}=12,8$ yang artinya anak jalanan berpeluang 12,8 kali untuk melakukan perilaku konsumsi alkohol dilihat berdasarkan lingkungan teman sebaya. Teman sebaya berperan penting terhadap perubahan perilaku seseorang, tidak hanya pengetahuan. Seseorang yang memiliki perilaku baik dapat berubah tidak baik hanya karena pemilihan teman sebaya yang salah.

Menurut Alpaqih (2015), konformitas sosial pada remaja peminum alkohol menemukan bahwa konformitas pada remaja cenderung menjadi proyeksi sosial remaja di mana seseorang yang mengonsumsi alkohol menjadi simbol bahwa seseorang tersebut berperan penting dalam kelompok dan memiliki konformitas kelompok. Konformitas pada dasarnya merupakan berubahnya suatu pola perilaku manusia akibat dari kelompok di mana seseorang cenderung selalu mengikut hal-hal yang dilakukan kelompok acuan tersebut. Tujuannya agar mereka terhindari dari siksaan ataupun celaan.

Hasil penelitian ini sejalan dengan jurnal Artha (2016) dari 250 responden didapatkan nilai $\mathrm{OR}=9,64$ yang artinya remaja memiliki peluang 9,64 kali lebih berisiko menjadi pengonsumsi alkohol dilihat berdasarkan dari teman sebaya.
Berdasarkan hasil penelitian yang didapatkan juga sesuai dengan hal yang dikemukakan oleh Santrock (2007) bahwa teman sebaya merupakan faktor yang memiliki peran yang cukup penting untuk pembentukan kepribadian seseorang. Teman sebaya merupakan sebuah dunia seorang remaja melakukan sosialisasi dengan suasana yang mereka ciptakan sendiri.

\section{SIMPULAN DAN SARAN}

\section{Simpulan}

Anak jalanan di Kota Kediri yang mengonsumsi alkohol dan memiliki pengetahuan yang kurang terhadap minuman beralkohol akan lebih mudah untuk mengonsumsi alkohol tanpa memikirkan bahaya serta dampak negatif yang ditimbulkan dari konsumsi alkohol. Sehingga dibutuhkan sikap yang tegas untuk menolak mengonsumsi alkohol karena adanya fakta bahwa lingkungan masyarakat di sekitar yang memang sudah terbiasa terhadap perilaku konsumsi alkohol dan tidak menganggap tabu hal tersebut. Selain itu, kemudahannya dalam mendapatkan alkohol semakin memperbesar kecenderungan anak jalanan di Kota Kediri untuk mengonsumsi alkohol dan meneruskan kebiasaan tersebut.

Berdasarkan faktor tingkat pengetahuan, sikap, keterjangkauan dan lingkungan teman sebaya yang memiliki peluang banyak untuk melakukan perilaku konsumsi alkohol adalah faktor keterjangkauan dengan nilai $\mathrm{OR}=15,8$ yang artinya anak jalanan berpeluang 15,8 kali melakukan perilaku konsumsi alkohol dilihat dari keterjangkauan minuman beralkohol. Variabel tersebut dianggap paling dominan sebagai penyebab besarnya kecenderungan anak jalanan di Kota Kediri untuk mengonsumsi alkohol dan meneruskan kebiasaan tersebut.

\section{Saran}

Saran yang dapat diberikan dari hasil penelitian ini adalah dengan mendirikan rumah singgah untuk anak jalanan di Kota Kediri sebagai sarana dalam mengurangi risiko kenakalan remaja pada anak jalanan. Pemerintah, khususnya Pemerintah Kota Kediri dalam hal ini instansi yang menangani tentang perlindungan anak serta dinas terkait dapat berperan aktif 
dalam pengawasan anak jalanan yang ada di rumah singgah tersebut. Adanya penyuluhan yang terintegrasi dan terjadwal kepada anak jalanan di Kota Kediri, secara tidak langsung efek yang akan ditimbulkan berupa hal positif akan dirasakan dalam jangka panjang. Selain itu, melibatkan anak jalanan dalam keaktifan terutama sosial keagamaan untuk membentuk perilaku positif pada anak jalanan. Saran penting yang dapat dilakukan yaitu memberikan penyuluhan tentang bahaya mengonsumsi alkohol di masyarakat Kota Kediri sehingga pengurangan risiko kenakalan remaja pada anak jalanan menjadi tanggung jawab bersama selamanya.

\section{DAFTAR PUSTAKA}

Artha P.W. 2016. Faktor-Faktor yang Mempengaruhi Tingginya Konsumsi Alkohol pada Remaja Putra di Desa Keramas Kecamatan Blahbatuh Kabupaten Gianyar. Bali: Jurnal Dunia Kesehatan.

Alpaqih, Rizal Amsar. 2015. Hubungan Konformitas Teman Sebaya dengan Perilaku Minum Minuman Keras pada Remaja Laki-Laki di Kelurahan Pekuncen RT 31 RW 07 Wirobrajan Yogyakarta. Skripsi.

Darmawan, S. 2010. Pengertian Minuman Keras dan Dampaknya. Jakarta: ECG.

Hapsari,K.M.2007.Skripsi MunculnyaAlkoholisme di Kalangan Mahasiswa. Semarang: Universitas Katolik Soegijapranata.

Hawari, D. 2006. Penyalahgunaan dan Ketergantungan NAZA (Narkotika, Alkohol \& Zat Adiktif). Jakarta: Raja Grafindo Persada.
Kalara, N., Siswanto, Y., Pranowowati, P. 2014. Gambaran Perilaku Konsumsi Alkohol pada Mahasiswa. perpusnwu.web.id/karyailmiah/ documents/3866.pdf [diakses tanggal 03 Maret 2017].

Karsono, E. 2005. Narkoba dan Minuman Keras. Jakarta: Gramedia. kel_10503088.pdf.

Kusuma, Y.L. 2015. Diktat Mata Kuliah Psikologi Untuk Tenaga Kesehatan. Surakarta: CV Kekata Group.

Narendra, M.S, dkk. 2002. Buku Ajar I Tumbuh Kembang Anak dan Remaja Edisi Pertama IDAI. Jakarta: Sagung Seto.

Nurwijaya, Dra. Hartati dan Prof. Zullies Ikawati Ph. D, dkk. 2009. Bahaya Alkohol dan Cara Mencegah Kecanduannya. Jakarta: Elex Media Komputindo.

Notoadmodjo, S. 2007. Promosi Kesehatan dan Ilmu Perilaku. Jakarta: Rhineka Cipta.

Mulyadi, M. 2014. Darurat Miras Oplosan. Jurnal, Vol. 5, No. 2.

Riskesdas. 2010. Laporan Nasional Riset Kesehatan Dasar. Jakarta: Departemen Kesehatan RI.

Yusuf, S. 2007. Psikologi Perkembangan Anak \& Remaja. Bandung: Remaja Rosdakarya.

Santrock, J.W. 2007. Adolescence (Perkembangan Remaja). Terjemahan. Jakarta: Erlangga.

Waluya, B. 2007. Menyelamati Fenomena Sosial di masyarakat untuk Kelas X Sekolah Menengah Atas. Jakarta: Raja Grafindo Persada.

WHO. 2014. Alkohol Health Topic. http://www. who.int/topics/alcohol_drinking/emn. Sitasi 31 Juli 2017 pukul 18.39 WIB. 